\title{
Silicon in Magnetite: High Resolution Microanalysis of Magnetite-Ilmenite Intergrowths *
}

\author{
Nancy G. Newberry ${ }^{1}$, Donald R. Peacor, Eric J. Essene, and John W. Geissman \\ Department of Geological Sciences, The University of Michigan, Ann Arbor, Michigan 48109, USA \\ Department of Geology, Colorado School of Mines, Golden, Colorado 80401, USA
}

\begin{abstract}
Magnetite-ilmenite "oxidation-exsolution" intergrowths from an original titanomagnetite microphenocryst from an ash flow tuff unit have been studied using conventional transmission electron microscopy and analytical electron microscopy. Silicon has been found to be in solid solution in all of the magnetite studied and in some of the coexisting ilmenite. The average value in magnetite is 1.2 wt. $\% \mathrm{Si}$, equivalent to solid solution of 9 mole $\%$ $\mathrm{Fe}_{2} \mathrm{SiO}_{4}$. Silicon is also present in very small silicate inclusions and as unusual Si-rich domains of uncertain origin in magnetite. The inclusions and domains may be irregularly distributed through the magnetite in sizes well below those resolvable with the electron microprobe. Microprobe analyses for $\mathrm{Si}$ in magnetite generally reflect these heterogeneities in addition to a component presumably in solid solution. The petrologic implications of the data can be assessed only when relevant thermochemical data become available and the distribution of $\mathrm{Si}$ in magnetite is better understood.
\end{abstract}

\section{Introduction}

Many workers report small amounts of silicon in electron microprobe and wet chemical analyses of magnetites. It is often assumed that this minor or trace $\mathrm{Si}$ is in the form of a contaminant phase whose size is below the level of resolution of the electron microprobe and does not represent a true solid solution of $\mathrm{Si}$ in magnetite. This may in part be due to a reluctance to propose solid solution of $\mathrm{Si}$ in an oxide structure. Solid solution of $\mathrm{Si}$ could have significant effects on the magnetic and thermodynamic properties of magnetite.

There are experimental data to suggest that silicon may substitute in spinels. Silicon has been shown to occur in cation-excess Ni-Ti spinels at high temperatures (Bayer and Flörke 1973; Armbruster 1981). Ma (1974a, b) has synthesized three intermediate phases between $\mathrm{NiAl}_{2} \mathrm{O}_{4}$ and $\mathrm{Ni}_{2} \mathrm{SiO}_{4}$ over a wide range of pressures, illustrating possible additional complexities in phase equilibria between spinels

1 Present address: EXXON Company USA, Midland, Texas 79701, USA

* Contribution No. 376 from the Mineralogical Laboratory, Department of Geological Sciences, The University of Michigan

Reprint requests to : N.G. Newberry and olivines. Certainly silicon-bearing spinels are stable at higher pressures than olivine (Ringwood and Major 1966; Akimoto et al. 1965; Akimoto 1972). Modreski and Chou (1981) have examined synthetic run products on the quartzmagnetite-fayalite (QFM) oxygen buffer and have concluded that the magnetite contains $7 \%$ fayalite in solution. Substitution of some silicon in magnetite may be more common than previously assumed. It has not been previously possible to completely resolve the problem of silicon in magnetite because the best available analytical tool, the electron microprobe, has a minimum resolution of more than a micron. Recent developments in analytical electron microscopy (AEM), in which a solid-state energy dispersive $\mathrm{X}$-ray detector is fitted to a scanning transmission electron microscope (STEM) allow for accurate chemical analyses of areas approaching $200 \AA$ in area. We have used a JEOL JEM 100-CX analytical electron microscope which has been extensively modified for chemical analysis and can produce excellent analytical results approaching the relative accuracy and limits of detection of electron microprobe analyses (Blake et al. 1980). The advantages of using STEM are great, the most important advantage of which is that the structure of the mineral can be directly imaged and high resolution analyses obtained from areas of known structure and orientation. With this combination of functions, we have analyzed individual lamellae of ilmenite and magnetite in coarse oxide intergrowths and have determined that some $\mathrm{Si}$ appears to be in solid solution in magnetite and much of the ilmenite at the STEM level of resolution.

\section{Sample Characterization}

The samples chosen for this investigation are from an Oligocene vitrophyre of the Mickey Pass Tuff cooling unit near Yerington, in western Nevada (Proffett and Proffett 1976). The vitrophyres form by rapid, violent eruption of pyroclastic material (Geissman et al. 1978; Smith 1979). Evidence that the rock has not subsequently been annealed is indicated by preservation of the glassy matrix. These fresh samples were chosen for detailed study of the distribution of Si because they have been well characterized using a variety of methods. The basal vitrophyre contains two distinct populations of magnetite: relatively coarse crystals (some up to $100 \mu \mathrm{m}$ in diameter) usually displaying intergrowths of magnetite and ilmenite (Fig. 1), and fine magnetite grains $(\geqq 100 \AA)$ without ilmenite lamellae (Newberry et al. 1980, and Geissman et al., in prep.). Our microprobe 


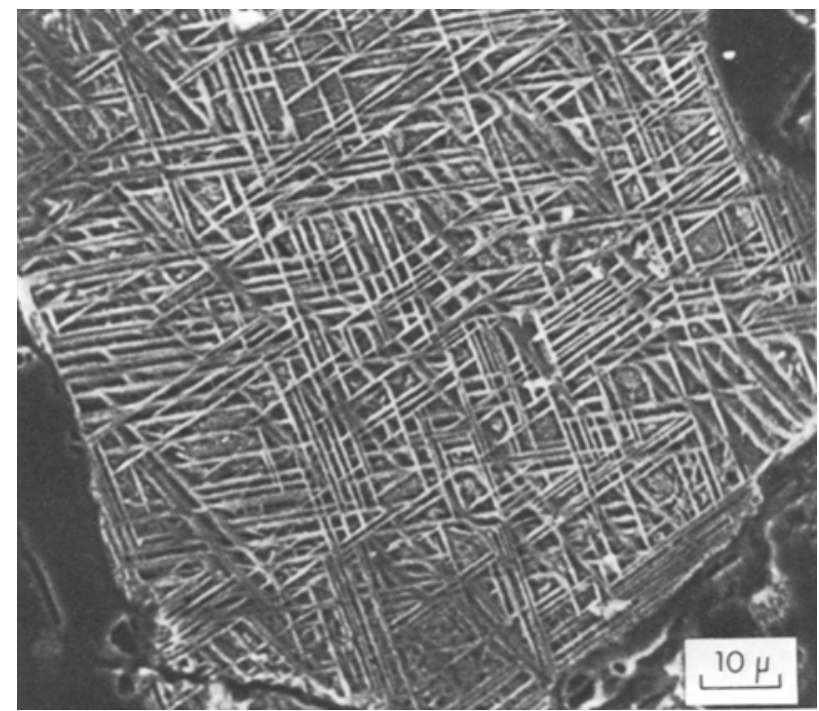

Fig. 1. SEM micrograph of a typical vitrophyre oxide phenocryst. The sample has been etched with the magnetite being preferentially dissolved away

analyses of the coarse magnetites consistently showed a few percent $\mathrm{Si}$ and preliminary scanning electron microscope (SEM) investigations with an SEM fitted with a solid state detector showed patchy areas where $\mathrm{Si}$ is concentrated. While the rocks bearing the magnetites which were examined by AEM and EMPA carried no primary igneous ilmenite phenocrysts, many other rocks in the Mickey Pass ashflow tuff sequence have phenocrysts of both magnetite and ilmenite (Geissman et al. 1978).

Rock magnetic properties of the vitrophyre have also been determined (Geissman 1980; Geissman et al., in prep.). Curie temperatures (between 570 and $580^{\circ} \mathrm{C}$ ) and blocking temperatures (between 500 and $580^{\circ} \mathrm{C}$ ) imply that the remanence is dominated by magnetite with little Ti. Coercivities of about $25 \mathrm{mT}$, coercivities of remanence about $40 \mathrm{mT}$, median destructive fields greater than $90 \mathrm{mT}$ and ratios of saturation remanence to saturation magnetization consistently greater than 0.25 all imply an abundance of singledomain and pseudo-single-domain magnetites in the vitrophyre (Parry 1965; Dunlop 1972; Stacey and Banerjee 1974). These grains, as will be shown in a separate paper (Geissman et al., in prep.), reside outside of the coarsely exsolved magnetite-ilmenite crystals.

\section{Experimental Procedures}

$\mathrm{X}$-rays may be generated from various parts of the electron microscope by several mechanisms (Zaluzec 1979). In order to eliminate the excitement of spurious $\mathrm{X}$-rays from parts of the column, sample holder or from other parts of the specimen it is essential that modifications be made to the instrument. We have carried out extensive modifications, as described by Blake et al. (1980), which ensure that X-rays which are detected are generated only directly by the focused electron beam. We refer to the significance of this work here because the results of this paper are critically dependent on high resolution analytical data which are not far above minimum detectable limits.

After completion of the instrument modification procedure, a number of well-analyzed standard materials were analyzed by STEM to create working curves to which the

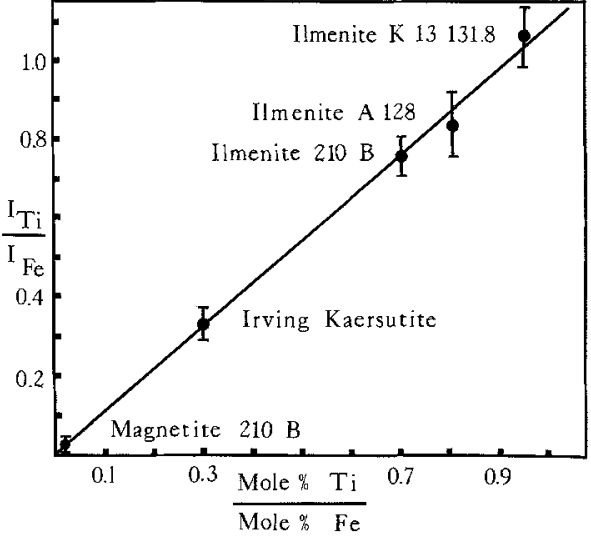

Fig. 2. Ti/Fe working curve used in STEM analyses

unknown oxides could be compared. The standards were crushed grain mounts on beryllium sample grids supported by carbon film. If thin, electron-transparent edges of grains are analyzed, the beam undergoes minimal spreading and passes directly through the thin sample rather than being absorbed as it is in electron microprobe analysis. No absorption, fluorescence or atomic number corrections need to be applied to the data if only thin films are analyzed. Spectra were analyzed by the method of Cliff and Lorimer (1975) in which ratios of peak areas for the two elements are plotted against known mole ratios. These plots should be straight lines that intersect the origin. Figure 2 is an example of such a plot for $\mathrm{Ti} / \mathrm{Fe}$, used for the magnetite and ilmenite analyses. Ilmenite standards A128 and K 13 131.8 were furnished by A.T. Anderson $(166,1968 \mathrm{~b})$. The slopes $(k)$ of such plots, with intensity and composition ratioed to corresponding values for $\mathrm{Si}$, have been shown by Cliff and Lorimer (1975) to vary in a regular way with atomic number $Z$. To a good approximation the slope $k_{Z, \mathrm{Si}}$ of such a function can thus be determined for any element of atomic number $\mathrm{Z}$ for which standard data are not available. Such a slope can then be used to determine the concentration of the element relative to $\mathrm{Z}$ if intensity ratios can be measured. Such a procedure was used initially to determine the Si concentration relative to $\mathrm{Fe}$ in magnetite, and subsequently confirmed with data for standards with both $\mathrm{Fe}$ and $\mathrm{Si}$. The concentrations of $\mathrm{Ni}$ and $\mathrm{Co}$ were obtained only using slope values predicted from atomic number and are thus subject to an additional, small error.

As part of an extensive testing of the method of analysis a wide variety of silicates were examined with a wide range of other major and minor elements and variable amounts of Si to prepare working curves. Elements reported in microprobe analyses of our standards to be present in concentrations greater than $0.5 \%$ are routinely detected by STEM analyses. The average of several STEM analyses accurately reproduces the microprobe result, though the precision of STEM analyses is relatively poor $( \pm 5 \%$ of the amount present). This is true of low atomic number elements, such as $\mathrm{Mg}$, through high atomic number elements, such as $\mathrm{Cr}$, although minimum detectable concentrations are greater at the lower atomic numbers. Therefore, our calculations of $\mathrm{Si}$ content, though made from raw $\mathrm{Si} / \mathrm{Fe}$ ratios which range from only 0.003 to 0.02 , must represent a Si concentration greater than the minimum amount detectable by our methods and the average of those analyses must be reasonably accurate. 
As an example of the precision and accuracy of the methods we can use our analysis of the standard ilmenite $\mathrm{K} 13$ 131.8. The $\mathrm{Ti}$ and $\mathrm{Fe}$ data were included in the data from which the $\mathrm{Ti} / \mathrm{Fe}$ working curves were constructed, so there is a significant bias. However the $\mathrm{Mg}$ values were independently determined using other mineral standards. The $M g$ results are especially significant since sensitivity and accuracy decrease with decreasing atomic number. The results for $\mathrm{Mg}$ should be the least precise of the elements analysed, and $\mathrm{Si}$ should be expected to give better results than $\mathrm{Mg}$. Anderson's (1968 b) analyses are: $\mathrm{Ti}=31.4 \mathrm{wt} . \%$; $\mathrm{Fe}$ (total) $=32.65 \mathrm{wt} . \%$; and $\mathrm{Mg}=2.42 \mathrm{wt} \%$. To approximate a microprobe analysis we have averaged the results from 10 small-area $(30$ by $30 \mu \mathrm{m})$ analyses giving: $\mathrm{Ti}=$ 31.9 et. $\% ; \mathrm{Fe}=33.3 \mathrm{wt} . \%$; and $\mathrm{Mg}=2.3 \mathrm{wt} . \%$. These averages correspond very well with Anderson's analysis but there is some variation in the individual small-area analyses. For example, the analyses with the highest and lowest $\mathrm{Mg} / \mathrm{Fe}$ ratios gave $\mathrm{Ti}=33.1$ and $29.9 ; \mathrm{Fe}=34.6$ and $31.7 ; \mathrm{Mg}=0.2$ and 4.9 wt. $\%$ respectively. However, the raw $\mathrm{Ti} / \mathrm{Fe}$ ratios are within $5 \%$ of the mean ratio for all of the analyses. Therefore, scatter in the analyses for minor elements is interpreted as heterogeneity in the sample (an important point in evaluating the results for $\mathrm{Si}$ distribution in magnetite). The other elements in Anderson's ilmenite analysis, reported at less than $0.5 \mathrm{wt} . \%$, were not detected by STEM analysis.

Standard ion-thinned samples of phenocryst magnetites from the vitrophyre were prepared for the STEM studies so that chemical analyses could be made on thin (electrontransparent) edge of magnetite lamellae and coexisting ilmenite laths. Additional analyses were made of domains within the magnetite which showed a higher concentration of silicon. Traverses across magnetite-ilmenite boundaries were made to search for trends in minor and major elements. The instrument can be operated in either a spot mode, which minimizes the beam size, or a small area mode, in which the area analyzed can be varied. Spectra were collected in most cases for 400 seconds to optimize counting statistics, but for small areas in which movements of the sample could become a significant factor, counting times were 200 seconds.

Preliminary SEM observations showed that the magnetite-ilmenite intergrowths are typical trellis-works of ilmenite laths parallel to the $\{111\}$ planes of host magnetite (Fig. 1). Ilmenite laths are usually only $1-3 \mu \mathrm{m}$ wide as compared with thicknesses up to 10 microns for magnetite regions. The ilmenite laths are not continuous flat plates of constant thickness, but taper near intersections with other ilmenite lamellae, as expected for an exsolved phase. It was not possible to analyze individual lamellae of ilmenite using the electron microprobe, but they are well within the size resolution limits of STEM microanalysis.

\section{Solid Solutions of Silicon in Magnetite}

STEM analyses were generally obtained in the stationary beam mode along linear traverses normal to magnetite-ilmenite boundaries. An averaged result for a series of closely spaced analyses of magnetite is shown in Table 1 along with an average of STEM analyses for an ilmenite lamellae adjacent to the analyzed magnetite area. The magnetite analysis is normal in all respects except for the relatively high $\mathrm{Si}$ content, which corresponds to a recalculated
Table 1. STEM and EMPA analyses of Yerington oxides. The first column is a typical STEM analysis of an ilmenite lamella, the second a STEM analysis of the adjacent magnetite host, and the third is an average of 7 integrated EMPA analyses of titanomagnetite phenocrysts

\begin{tabular}{lrrc}
\hline $\mathrm{Wt} \%$ oxides & & & \\
$\mathrm{SiO}_{2}$ & $<0.1$ & 2.5 & 1.05 \\
$\mathrm{TiO}_{2}$ & 46.4 & 4.5 & 14.3 \\
$\mathrm{Al}_{2} \mathrm{O}_{3}$ & $<0.1$ & 2.7 & 2.5 \\
$\mathrm{Cr}_{2} \mathrm{O}_{3}$ & $<0.1$ & 0.1 & 0.04 \\
$\mathrm{Fe}_{2} \mathrm{O}_{3}{ }^{\mathrm{a}}$ & 11.9 & 51.2 & 35.7 \\
$\mathrm{FeO}^{\mathrm{a}}$ & 38.1 & 38.6 & 43.8 \\
$\mathrm{MnO}$ & 3.1 & 0.4 & 1.0 \\
$\mathrm{NiO}$ & 0.5 & - & - \\
$\mathrm{MgO}$ & $<0.1$ & $<0.1$ & 0.8 \\
$\mathrm{Sum}$ & $\equiv 100.0$ & $\equiv 100.0$ & 99.2
\end{tabular}

Atomic ratios

$\begin{array}{lrrl}\mathrm{Si} & <0.01 & 0.09 & 0.039 \\ \mathrm{Ti} & 0.89 & 0.13 & 0.40 \\ \mathrm{Al} & <0.01 & 0.12 & 0.11 \\ \mathrm{Fe}^{3+\mathrm{a}} & 0.23 & 1.44 & 1.00 \\ \mathrm{Fe}^{2+\mathrm{a}} & 0.81 & 1.21 & 1.37 \\ \mathrm{Mn} & 0.07 & 0.01 & 0.03 \\ \mathrm{Ni} & 0.01 & - & - \\ \mathrm{Mg} & <0.01 & <0.01 & 0.04 \\ \mathrm{O} & \equiv 3.00 & \equiv 4.00 & \equiv 4.00\end{array}$

Components

\begin{tabular}{lrrrl}
$\mathrm{FeTiO}_{3}$ & 81 & 13 & 40 & $\mathrm{Fe}_{2} \mathrm{TiO}_{4}$ \\
$\mathrm{Fe}_{2} \mathrm{O}_{3}$ & 12 & 52 & 43 & $\mathrm{Fe}_{3} \mathrm{O}_{4}$ \\
$\mathrm{MnTiO}_{3}$ & 7 & 0 & 3 & $\mathrm{MnFe}_{2} \mathrm{O}_{4}$ \\
& & 6 & 6 & $\mathrm{FeAl}_{2} \mathrm{O}_{4}$ \\
& & 0 & 4 & $\mathrm{MgFe}_{2} \mathrm{O}_{4}$ \\
& & 9 & 4 & $\mathrm{Fe}_{2} \mathrm{SiO}_{4}$ \\
\hline
\end{tabular}

a $\mathrm{Fe}^{2+}$ and $\mathrm{Fe}^{3+}$ estimated by assuming stoichiometry, normalizing to cations and calculating the expected oxygen by adjusting $\mathrm{Fe}^{2+} / \mathrm{Fe}^{3+}$

$\mathrm{Fe}_{2} \mathrm{SiO}_{4}$ component of 9 mole percent, a value comparable to the ulvöspinel component. The Si content is consistent with that obtained by quantitative EMPA (Table 1) analysis. We believe that we have convincing evidence that $\mathrm{Si}$ is in solid solution in our samples both for reasons outlined in the previous section and elucidated below.

The presence of $\mathrm{Si}$ in the Yerington magnetite, even at levels near the limit of detectability, is confirmed by the observation that the analyses reported here, averaged to calculate a Si content of $1.2 \%$, were taken at the same time and under identical conditions as analyses of adjacent lamellae of ilmenite in which $\mathrm{Si}$ was entirely undetectable in this sample (Table 1). The area of magnetite examined was not more than $2 \mu \mathrm{m}$ away from the Si-free ilmenite analyzed. This confirms that the $\mathrm{Si}$ is not a spectral contamination peak from the microscope column or from any other source, and arises from a true $\mathrm{Si}$ content of the volume of magnetite analyzed. Only octahedrally coordinated sites are occupied in the hexagonal closest-packed ilmenite structure whereas octahedral and tetrahedral sites are occupied in cubic closest-packed magnetite. As Si clearly prefers tetrahedral sites, it should be expected on crystal-chemical grounds to prefer the magnetite structure. However, other ilmenite analyses, obtained at other times and on different lamellae, exhibited Si contents equivalent to those of the host magnetite and thus in the range of 1 to 2 percent. 


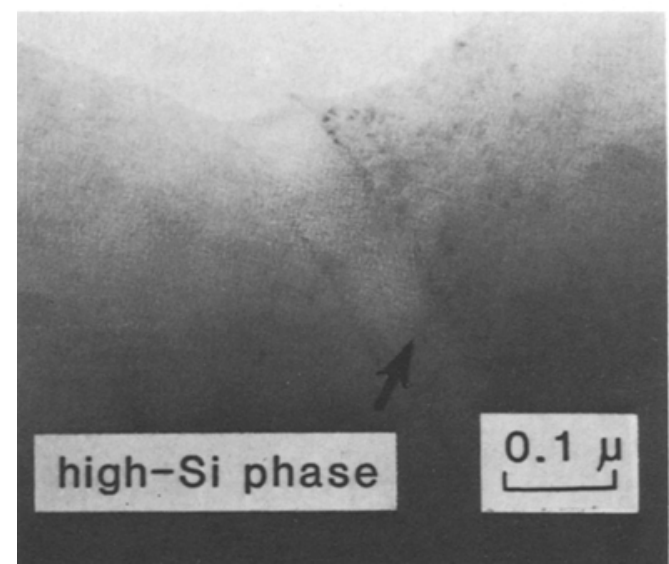

Fig. 3. Silicon-rich region within homogeneous magnetite, whose nature and origin remain incompletely characterized

All areas analyzed were examined at very high magnification, routinely at 100,000 to 250,000 times. The Si-bearing areas at all times appeared to be homogeneous and free of imperfections in conventional transmitted electron images. In addition, $\{111\}$ lattice fringe images of some of the Si-bearing areas were obtained. These lattice fringe images are regular $5 \AA$ fringes with no apparent defects. The perfection of these fringes verifies that the structure is free of dislocations or contaminating phases, and that $\mathrm{Si}$ is in the magnetite structure with no apparent perturbation of that structure. The existence of $1.2 \% \mathrm{Si}$ in a region of such perfect structure can only be interpreted as due to substitution of $\mathrm{Si}$ in magnetite.

\section{High-Silicon Domains within Magnetite Lamellae}

Silicon was found not only in low levels homogeneously distributed in magnetite, but in higher concentrations in domains within the magnetite lamellae. The domains are in general lath-shaped, parallel to $\{111\}$ and $200-600 \AA$ wide, well below the levels of resolution of the electron microprobe. They exhibit a brighter contrast than the surrounding normal magnetite (Fig. 3), which first called them to our attention, and which may be due to less resistance to the ion thinning process. Typical $\mathrm{Si}$ contents of these domains of 5 weight percent $\mathrm{Si}$ result in recalculated $\mathrm{Fe}_{2} \mathrm{SiO}_{4}$ components of 36 mole percent. The domains are crystallographically continuous with the surrounding magnetite and no weak reflections appear in electron diffraction patterns which would indicate the presence of a superstructure or the existence of a phase other than magnetite. Ti is also noticeably low in these regions, appearing in amounts less than 2 weight percent corresponding to an ulvöspinel component of less than 6 mole percent.

The high-Si domains are fairly evenly distributed throughout the magnetite-ilmenite phenocrysts and do not become more abundant at the edges of grains. Electron diffraction results provide no evidence that these domains have other than magnetite structure. The high-silicon domains are elongated parallel to $\{111\}$ and in most cases have relatively straight boundaries. They may represent exsolution of a fayalite-rich spinel as a metastable step on the way to forming a more stable olivine structure upon

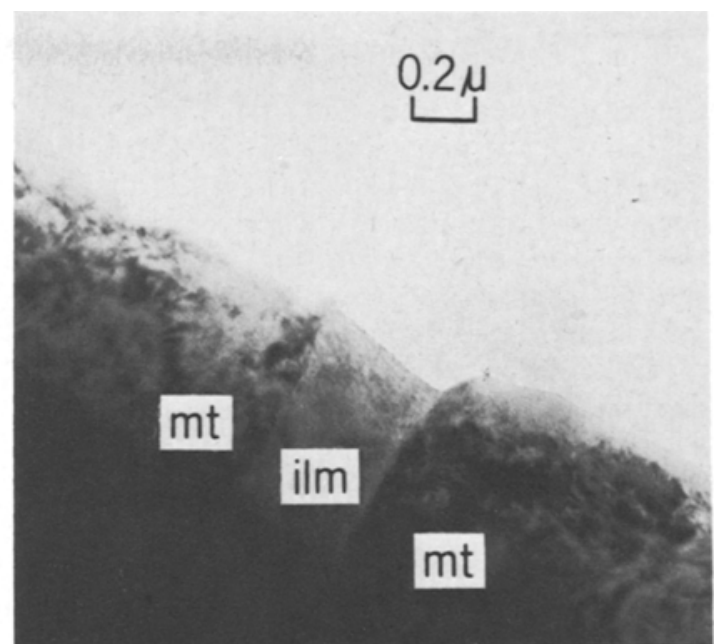

Fig. 4. Ilmenite lath bordered by magnetite

cooling. Because these domains have sizes which are below the limits of resolution of the electron microprobe, and because they are fairly evenly distributed throughout the magnetite, EMPA would yield concentrations of $\mathrm{Si}$ in magnetite that are much greater than the average amount which we find in solid solution by STEM analysis.

\section{Ilmenite Laths and the Magnetite-Ilmenite Boundary}

The ilmenite STEM analysis in Table 1 is generally similar to other igneous ilmenites. In analyses of other ilmenite laths we found ca. $1 \mathrm{wt} . \% \mathrm{Si}$, similar to that for the magnetite host. The cause of the variable $\mathrm{Si}$ is not well understood. The ilmenite generally is featureless and homogeneous when observed using standard CTEM techniques, but does show considerable variation in minor element content between different lamellae. The one significant and reproducible difference in minor element composition between the magnetite and ilmenite is in the $\mathrm{Mn}$ content which is generally much greater in the ilmenite, as observed in macroscopic ilmenite vs. magnetite.

The boundaries between magnetite and ilmenite (Fig. 4) were examined for any trends in the distribution of either major or minor elements. Analyses were taken with $\{111\}$ planes parallel to the beam, so that analyses do not represent overlap of the two phases as would be the case if the boundary were inclined. All boundaries were found to be chemically and structurally sharp, with the only apparent trend being relatively high $\mathrm{Si}(2-3 \%)$ content in the magnetite at the boundary itself. It is tentatively concluded possible that $\mathrm{Si}$ diffuses out of the ilmenite and into the boundary region between magnetite and ilmenite during the oxidation-exsolution origin of ilmenite. Titanium was found to be homogeneously distributed, and minor amounts of $\mathrm{Ni}$ and $\mathrm{Cr}$ were found in both magnetite and ilmenite. Analyses taken only $200 \AA$ from the boundary show the characteristic $\mathrm{Ti} / \mathrm{Fe}$ ratios of magnetite or ilmenite. Intermediate values for $\mathrm{Ti} / \mathrm{Fe}$ obtained directly on the boundary are believed to arise because the sharpness of the boundary challenges the limits of spatial resolution of STEM microanalysis and not because of the existence of an intermediate phase of complicated chemical gradients. 
Microprobe Analysis of Titanomagnetite Microphenocrysts

Microprobe analyses were made using the University of Michigan ARL-EMX microprobe in a wavelength dispersive mode using $\mathrm{LiF}, \mathrm{ADP}$, and TAP crystal spectrometers. Details of analytical procedures are described by Bohlen and Essene (1977). Average results for titanomagnetite grains (magnetite-ilmenite intergrowths) were obtained by stepping across individual crystals taking approximately 50 readings per grain. Special care was taken to avoid integrating mineral inclusions into the magnetite analysis. The commonly included zircon and apatite were easily avoided due to their characteristic reflectivity and cathodoluminescence. Analysis of seven different phenocrysts gave results ranging over $\mathrm{Mt}_{35-55} \mathrm{Uv}_{36-55} \mathrm{Fa}_{0.5-7.7} \mathrm{He}_{5-8} \mathrm{Jb}_{3} \mathrm{Mf}_{4}{ }^{*}$. The average of the EMPA analyses is presented in Table 1. Individual crystals were clearly variable in $\mathrm{Si}$ content with results ranging from 0.15 to $2.1 \mathrm{wt} . \% \mathrm{SiO}_{2}$. The average $1.05 \mathrm{wt} \% \mathrm{SiO}_{2}$ is less than the STEM value of $2.5 \mathrm{wt} \%$ but this is in part due to the integration of ilmenite having lower $\mathrm{Si}$ concentrations into the EMPA results. The variation in $\mathrm{Si}$ on all scales, from phenocryst to phenocryst, down to the $200 \AA$ scale found on the STEM, makes any closer comparison difficult, especially as the STEM and EMPA analyses are from different grains.

\section{Interpretation and Discussion}

All available data are consistent with solution of some $\mathrm{Si}$ in magnetite presumably on the tetrahedral site, charge balanced as a normal spinel: $(\mathrm{Si})^{\mathrm{IV}}\left(\mathrm{Fe}^{2+}\right)_{2}^{\mathrm{VI}} \mathrm{O}_{4}$, and hence a fayalite component. It should be recast into the formula as in Table 1 and in Deer et al. (1962).

The siliceous magnetites reported here are generally similar to those reported by other workers in analyses of igneous magnetites (e.g. Anderson 1966, 1968 a; Duchesne 1972; Czamanske and Mihalik 1972; Puffer 1972, 1975; Bauer et al. 1973; Petrova and Tatarsky 1975; Haggerty 1976; Whitney and Stormer 1976; Shcheka et al. 1977; Modreski and Chou 1981). However, some of these workers (e.g. Duchesne 1972; Puffer 1972; Puffer 1972, 1975; Petrova and Tatarsky 1975; Haggerty 1976) reported analyses of bulk separates where some contamination by silicates is unavoidable and these workers generally report higher silicon in magnetite. Even microprobe analysis may be suspect where submicroscopic silicate inclusions might be encountered.

Petrova and Tatarsky (1975) and Shcheka et al. (1977) note correlation of $\mathrm{Ca}$ and $\mathrm{Mg}$ with $\mathrm{Si}$ suggesting substitution of $\mathrm{Ca}_{2} \mathrm{SiO}_{4}$ and/or $\mathrm{Mg}_{2} \mathrm{SiO}_{4}$ in magnetites. Shcheka et al. further note optical anisotropy for magnetites rich in $\mathrm{Ca}_{2} \mathrm{SiO}_{4}$. The possibility of a submicroscopic contaminant such as clinopyroxene should not be excluded in explaining these observations, and electron microscopic studies are needed on these samples. Assuming for the present that microprobe analyses are dependable, the following generalizations may apply: basaltic, kimberlitic and metamorphic magnetites generally have little $\mathrm{Si}(\leqq 0.5 \mathrm{wt} . \%$ $\mathrm{SiO}_{2}$ ), while those from high-level granites and from rhyolitic rocks may bear higher contents (up to 2 or $3 \mathrm{wt} \%$ $\mathrm{SiO}_{2}$ ).

\footnotetext{
$* \mathrm{Mt}=\mathrm{Fe}_{3} \mathrm{O}_{4}, \mathrm{Uv}=\mathrm{Fe}_{2} \mathrm{TiO}_{4}, \mathrm{Fa}=\mathrm{Fe}_{2} \mathrm{SiO}_{4}, \mathrm{Hc}=\mathrm{FeAl}_{2} \mathrm{O}_{4}, \mathrm{Jb}=$ $\mathrm{MnFe}_{2} \mathrm{O}_{4}, \mathrm{Mf}=\mathrm{MgFe}_{2} \mathrm{O}_{4}$
}

The petrologic implications of $\mathrm{Fe}_{2} \mathrm{SiO}_{4}$ substitution in magnetite are difficult to assess quantitatively. The heterogeneous $\mathrm{Fe}_{2} \mathrm{SiO}_{4}$ content of the Mickey Pass titanomagnetite phenocrysts suggests either that they equilibrated under variable $f \mathrm{O}_{2} / \mathrm{T}$ conditions, that their Si contents have been variably reset during oxidation-exsolution of ilmenite, or that $\mathrm{Si}$ substitution in titanomagnetite was controlled by kinetic or disequilibrium processes. The following discussion is predicated on the assumption of an equilibrium level of $\mathrm{Si}$ in magnetite. The solid solution should be maximized at high activities of fayalite as encountered in rhyolites and fayalite granites. It should also be favored at high temperatures where the miscibility of fayalite in magnetite (and vice-versa?) should be highest. The temperature effect is qualitatively confirmed by noting that Bohlen and Essene's (1977) microprobe analyses of magnetites in charnockites, equilibrated at $700 \pm 50^{\circ} \mathrm{C}$ and near QFM, have $\leqq 0.1$ wt. $\% \mathrm{SiO}_{2}$. The substitution of $\mathrm{Fe}_{2} \mathrm{SiO}_{4}$ should be less in more magnesian rocks such as basalts and peridotites where the activity of fayalite is reduced. Pressure may also be expected to have a significant effect on the substitution of silicon in magnetite. Fayalite transforms to a spinel structure at ca. $60 \mathrm{~kb}$ at $1,000^{\circ} \mathrm{C}$ (Akimoto et al. 1955) while forsterite transforms to a related structure at ca. $140 \mathrm{~kb}$ at $1,000^{\circ} \mathrm{C}$ (Ringwood and Major 1966; Akimoto 1972). While the mutual solubility of magnetite and olivine composition spinel are unknown at high pressures, it may be expected that $\mathrm{Fe}_{2} \mathrm{SiO}_{4}$ dissolves in $\mathrm{Fe}_{3} \mathrm{O}_{4}$ to a considerably greater extent than $\mathrm{Mg}_{2} \mathrm{SiO}_{4}$ in $\mathrm{Fe}_{3} \mathrm{O}_{4}$ because $\mathrm{Fe}_{2} \mathrm{SiO}_{4}$ is stable as a spinel at much lower pressures than $\mathrm{Mg}_{2} \mathrm{SiO}_{4}$ (Modreski and Chou, 1981). Thus, pressure, temperature and the $a_{\mathrm{Fe}_{2} \mathrm{SiO}_{4}} / a_{\mathrm{Mg}_{2} \mathrm{SiO}_{4}}$ should all have an important effect on the substitution of silicon in magnetite. Carefully reversed experiments are needed in order to evaluate each of these dependencies and to obtain quantitative petrological information from the solution of silicon in magnetite. If activity-composition relations can be quantified for fayalite solution in magnetite, activities of fayalite could be obtained from accurate analyses of $\mathrm{Si}$ in magnetite and used in calculations where olivine is absent. This may allow application of an adjusted quartz-fayalite-magnetite (QFM) buffer to the common assemblages of quartz-magnetite without olivine. Modreski and Chou (1981) have also noted up to $10 \mathrm{~mol} \% \mathrm{Fe}_{2} \mathrm{SiO}_{4}$ in natural magnetites and in synthetic magnetites grown on the QFM buffer. They calculate an activity coefficient of 1.4 for $\mathrm{Fe}_{2} \mathrm{SiO}_{4}$ solid solution in magnetite relative to the spinel-olivine transition in $\mathrm{Fe}_{3} \mathrm{O}_{4}$. With this activity coefficient or with an ideal model and an estimated P-T, one may predict approximately correct $X_{\mathrm{Fe}_{2} \mathrm{SiO}_{4}}$ in high-Si magnetites (Modreski and Chou 1981), but the low-Si magnetites often found in the same rocks remain unexplained. Until the substitution of silicon and its variability in magnetites is better understood, it should not be used for quantitative calculations of pressure.

The information gathered thus far on the Mickey Pass oxides allows some constraints to be placed on $\mathrm{P}, \mathrm{T}$ and $f \mathrm{O}_{2}$ during formation of the tuff. Several models for twopyroxene and two-feldspar geothermometers have been applied to the rocks to obtain equilibration temperatures of $700-950^{\circ} \mathrm{C}$, in good agreement with those of $700-930^{\circ} \mathrm{C}$ and $f \mathrm{O}_{2}$ of $10^{-12.5 \pm 1.5}$ given by oxide thermometry obtained from ilmenite and titanomagnetite phenocrysts in nearby tuffs (Geissman et al. 1978). These appear to correspond to conditions in a relatively high-level magma chamber 
where the phenocrysts presumably formed. The compositions of the coexisting lamellar ilmenite and magnetite allow estimation of conditions during the oxidation-exsolution event. The ilmenite lamellae are judged large enough that coherency effects are unlikely to be significant. Buddington and Lindsley's (1964) thermometry, applied using the 12 mole percent hematite in lamellar ilmenite and 13 mole percent ulvöspinel in host magnetite, yields $f \mathrm{O}_{2}=10^{-17}$ for $\mathrm{T}$ of $650^{\circ} \mathrm{C}$. A $25 \%$ error for the percent hematite and ulvöspinel components produce errors of $10^{ \pm 2}$ in $f \mathrm{O}_{2}$ and $\pm 40^{\circ} \mathrm{C}$ in temperature. The "igneous" (taken as conditions prevailing in a pre-eruptive magma chamber) and " $\mathrm{ex}$ solution" (taken as conditions extant just after eruption and during welding of the ashflow tuff) parameters inferred are located one to two orders of magnitude more oxidizing than QFM and close to NNO, suggesting that the ashflow tuffs are self-buffered along a $\mathrm{fO}_{2}$-T line parallel to simple buffering systems during eruption and afterwards while cooling. This trend is similar to the more detailed paths inferred by Sato and Wright (1966) for cooling Hawaiian basalt and by Carmichael (1967) and Ewart et al. (1971) for acidic volcanics. Magnetic blocking temperatures of $540 \pm 40^{\circ} \mathrm{C}$ in bulk samples of the vitrophyre arise from submicroscopic magnetites (Geissman 1980; Geissman et al., in prep.) presumably corresponding to later alteration and further oxidation during continued cooling of the Mickey Pass tuff. Combination of petrologic, magnetic and AEM studies has allowed inference of physico-chemical parameters prevailing at different times in the history of this vitrophyre.

Acknowledgements. We thank Larry F. Allard, Wilbur C. Bigelow and David F. Blake for their efforts in maintaining and operating the STEM. We thank A.T. Anderson, Jr. for microprobe and STEM standards, Allen H. Treiman and Chad McCabe for helpful discussion of the results, and A. John Mardinly for technical assistance. We are grateful to the Anaconda Copper Company for permission to sample the Yerington vitrophyre on their claims. Drs. C.K. Czamanske and J.C. Stormer, Jr. reviewed the manuscript and contributed many helpful suggestions for change. This research was supported by National Science Foundation Grant EAR 78-022758 and by the Scott Turner Fund, University of Michigan.

\section{References}

Akimoto S, Fujisawa H, Katsura T (1965) The olivine-spinel transition in $\mathrm{Fe}_{2} \mathrm{SiO}_{4}$ and $\mathrm{Ni}_{2} \mathrm{SiO}_{4}$. J. Geophys Res 70:1969-1977

Akimoto $\mathrm{S}(1972)$ The System $\mathrm{MgO}-\mathrm{FeO}-\mathrm{SiO}_{2}$ at high pressures and temperatures - phase equilibria and elastic properties. Tectonophys 13:161-187

Allard LF, Blake DF, Newberry NG, Peacor DR, Bigelow WC (1980) Microanalysis of geological materials in an analytical electron microscope: elimination of spectral contamination (abstr.). Am Geophys Union Trans 61:398

Anderson AT Jr (1966) Mineralogy of the Labrieville anorthosite, Quebec. Am Mineral 51:1671-1711

Anderson AT Jr (1968a) The oxygen fugacity of alkaline basalt and related magmas, Tristan da Cunha. Am J Sci 266:704-727

Anderson AT Jr (1968 b) Oxidation of the LaBlache lake titaniferous magnetite deposit, Quebec. J Geol 76:528-547

Armbruster TH (1981) $\mathrm{SiO}_{2}$-solubility in cation-excess spinels $\mathrm{Ni}_{2(1+\mathrm{x})} \mathrm{Ti}_{(1-\mathrm{x})} \mathrm{O}_{4}$. Neues Jahrb Mineral Monatsh 1981:11-22

Bauer GR, Fodor RV, Husler JW, Keil K (1973) Contributions to the mineral chemistry of Hawaiian rocks. III. Composition and mineralogy of a new rhyodacite occurrence. Contrib Mineral Petrol 40:183-194
Bayer G, Florke OW (1973) A new spinel type phase in the system $\mathrm{NiO}-\mathrm{TiO}_{2}-\mathrm{SiO}_{2}$. Naturwiss 60:102

Blake DF, Allard LF, Peacor DR, Bigelow WC (1980) Ultraclean X-ray spectra in the JEOL JEM-100 CX. Proc Elect Micros Soc Amer 38:136-137

Bohlen SR, Essene EJ (1977) Feldspar and oxide thermometry of granulites in the Adirondack highlands. Contrib Mineral Petrol 62:153-169

Buddington AF, Lindsley DH (1964) Iron-titanium oxide minerals and synthetic equivalents. J Petrol 5:310-37

Carmichael ISE (1967) The iron-titanium oxides of salic volcanic rocks and their associated ferromagnesium silicates. Contrib Mineral Petrol 15:24-66

Cliff $\mathrm{G}$, Lorimer GW (1975) The quantitative analysis of thin films. J Micros 103: 203-207

Czamanske GK, Mihalik P (1972) Oxidation during magmatic differentiation. Finnmarka Complex, Oslo area, Norway: Part I, The opaque oxides. J Petrol 14:493-509

Deer WA, Howie RA, Zussman J (1962) Rock-forming Minerals. Vol 5, Nonsilicates. Longmans London

Duchesne JC (1972) Iron-titanium oxide minerals in the BjerkremSogndal Massif, south-western Norway. J Petrol 13:57-81

Dunlop DJ (1972) Magnetite: Behavior near the single-domain threshold. Science 176:41-43

Ewart A, Green DC, Carmichael ISE, Brown FH (1971) Voluminous low-temperature rhyolitic magmas in New Zealand. Contrib Mineral Petrol 33:128-144

Geissman JW, Mathews MJ, Essene EJ (1978) Inferred T, $P_{\text {total }}$, and $\mathrm{P}_{\mathrm{H}_{2} \mathrm{O}}$ pre-eruption equilibration conditions for an ash-flow tuff unit in Western Nevada (abstr.). Am Geophys Union Trans $59: 1212$

Geissman JW (1980) Paleomagnetism and tectonics of the Yerington (porphyry copper) mining district, Nevada. $\mathrm{PhD}$ dissertation Univ. Michigan Ann Arbor

Geissman JW, Newberry NG, Peacor DR (in prep.) Discrete singleand pseudo-single domain magnetites documented using STEM

Haggerty SE (1976) Opaque mineral oxides in terrestrial igneous rocks. In: Oxide Minerals. Mineral Soc Am Short Course Notes 3: $\mathrm{Hgl}-300$

Lorimer GW, A1-Salman SA, Cliff G (1977) The quantitative analysis of thin specimens: Effects of absorption, fluorescence and beam spreading. Inst Phys Conf Ser 36:369-372

$\mathrm{Ma} \mathrm{C}-\mathrm{B}$ (1974a) New orthorhombic phases on the join $\mathrm{NiAl}_{2} \mathrm{O}_{4}$ (spinel analog) $-\mathrm{Ni}_{2} \mathrm{SiO}_{4}$ (olivine analog): Stability and implications to mantle mineralogy. Contrib Mineral Petrol 45:257-279

$\mathrm{Ma} C-\mathrm{B}(1974 \mathrm{~b})$ New orthorhombic phases on the join $\mathrm{NiAl}_{2} \mathrm{O}_{4}-$ $\mathrm{Ni}_{2} \mathrm{SiO}_{4}$ : a discussion of possible crystal structures. Neues Jahrb Mineral Monatsh 1974:113-126

Modreski PJ, Chou I-M (1981) The silica content of magnetite from the fayalite-magnetite-quartz assemblage and from hydrothermal ore deposits. Geol Soc Am Abstr Prog 13:513

Newberry NG, Geissman JW, Peacor DR (1980) Discrete single and pseudo-single domain magnetites documented with scanning transmission electron microscopy (abstr.). Am Geophys Union Trans $61: 224$

Parry LG (1965) Magnetic properties of dispersed magnetite powders. Philos Mag 11:303-312

Petrova LV, Tatarsky VB (1975) Silica-lime magnetite of Korshunovskoye deposit. Zap Vses Mineral Obshch 103:301-309

Proffett JM Jr, Proffett BH (1976) Stratigraphy of the Tertiary ash-flow tuffs in the Yerington district, Nevada. Nevada Bur Mines Geol Rep 27, Reno

Puffer JH (1972) Iron-bearing minerals as indicators of intensive variables pertaining to granitic rocks from the Pegmatite points area, Colorado. Am J Sci 272:273-289

Puffer JH (1975) Some North American iron-titanium oxide bearing pegmatites. Am J Sci 275:708-732

Ringwood AE, Major AJ (1966) Some high-pressure transformations in olivines and pyroxenes. J Geophys Res 67:1975-1985

Sato M, Wright TL (1966) Oxygen fugacities directly measured in volcanic gases. Science 153:1103 1105 
Shcheka SA, Romanenko IM, Chuburov UM, Kurentsova NA (1977) Silica-bearing magnetites. Contrib Mineral Petrol 63:103-111

Smith D (1970) Mineralogy and petrology of the diabase rocks at a differentiated olivine diabase sill complex. Contrib Mineral Petrol 27:97-113

Smith PJ (1967) Electron probe microanalysis of optically homogeneous titano-magnetites and ferrian ilmenites in basalts of paleomagnetic significance. J Geophys Res 72:5087-5100

Smith RL (1979) Ash-flow magmatism. In: Chapin CE, Elston WE (eds) Ash-flow tuffs. Geol Soc Am Spec Pap 180:5-27

Stacey FD, Banerjee SK (1974) The physical principles of rock magnetism. Developments in solid earth geophysics 5. Elsevier Amsterdam

Whitney JA, Stormer JC Jr (1976) Geothermometry and geobarometry in epizonal granitic intrusions: A comparison of irontitanium oxides and coexisting feldspars. Am Mineral 61:751-763

Zaluzec NJ (1979) Quantitative X-ray microanalysis: instrumental considerations and applications to materials science. In: Hren JJ, Goldstein JI, Joy DC (eds) Introduction to analytical electron microscopy. Plenum Press New York, ch 4

Received August 7, 1981; Accepted July 8, 1982 